Article

\title{
Regional Economic Impacts from Timber Check Dam Construction-A Comparison with Concrete Check Dam Construction
}

\author{
Tomohumi Huzita $^{1, *}$, Ryu Noda ${ }^{2}$ and Chihiro Kayo ${ }^{3}$ \\ 1 United Graduate School of Agricultural Science, Tokyo University of Agriculture and Technology, \\ 3-5-8 Saiwai-cho, Fuchu, Tokyo 183-8509, Japan \\ 2 Institute of Wood Technology, Akita Prefectural University, 11-1 Kaieizaka, Noshiro, Akita 016-0876, Japan; \\ noda@iwt.akita-pu.ac.jp \\ 3 Institute of Agriculture, Tokyo University of Agriculture and Technology, 3-5-8 Saiwai-cho, Fuchu, \\ Tokyo 183-8509, Japan; kayoc@cc.tuat.ac.jp \\ * Correspondence: s195462r@st.me.tuat.ac.jp
}

Received: 19 August 2020; Accepted: 5 October 2020; Published: 8 October 2020

\begin{abstract}
Recently, many mountain disasters caused by natural phenomena, such as typhoons and heavy rains, have struck Japan, where check dams are used as important disaster prevention structures. Meanwhile, increased timber use in Japan is expected to revitalize regional economies, thus drawing attention to the use of timber in check dams. However, comparisons between timber and concrete check dams, in terms of their impact on the regional economy, have been overlooked in previous studies. Therefore, targeting Akita Prefecture in Japan, we evaluated quantitatively the respective regional economic impact of timber and concrete check dam construction through an input-output analysis. An extended input-output table was developed based on the revenue and expenditure data obtained from interviews with check dam construction companies. The construction cost and amount of sediment runoff prevention of a concrete check dam was unified with those of a timber check dam to evaluate their respective economic impact. In both cases, the impact of timber check dam construction was about 12 to $13 \%$ larger. In brief, timber check dam construction was found to have a more positive impact on the regional economy than concrete check dam construction. However, with the regional self-sufficiency ratio of the lumber and wood products sector at less than $20 \%$, or the lumber price at $60 \%$ of its current price, the economic impact of constructing a timber check dam becomes smaller than that of a concrete check dam. In other words, it is important to harvest, process, and use timber regionally to contribute to the regional economy. Specifically, using timber that is processed, rather than simply harvested, in the region has a larger economic impact on the region. Additionally, in timber check dam construction, procuring inexpensive timber and reducing construction costs may be a trade-off for revitalizing the regional economy.
\end{abstract}

Keywords: economic impact; timber check dam; forestry conservation; input-output table; forestry; timber-related industries

\section{Introduction}

To prevent the erosion of rivers and to maintain forests that face mountain streams, check dams are constructed. When check dams are constructed on a mountain stream, they stop unstable sediment from flowing downstream. In recent years, many mountain disasters, caused by typhoons, heavy rains, and other catastrophes, have been reported in Japan; the damage in 2019 was massive, amounting to approximately 64.4 billion yen [1]. In such situations, the Forestry Agency of Japan constructs check dams to lessen or prevent mountain disasters and to restore devastated mountain streams [1]. In areas 
where there are many steep and vulnerable geological areas, such as Japan, check dams are one of the most important disaster prevention structures.

Additionally, in Japan, timber is promoted for the effective use of artificial forests that have reached a suitable age for logging and as a measure to alleviate global warming and revitalize forestry. As such, timber use for check dams is drawing increased attention [2,3]. As timber use involves various industries such as forestry, and the timber industry (which includes production, processing, transportation, and construction) is regionally based, it plays an important role in a region's economy. Timber use for check dams not only contributes to maintaining and improving the function of a forest, but it may also contribute to the revitalization of regional economies. Therefore, it is important to show quantitatively the regional economic impact of timber check dam construction.

However, the literature on timber check dams focuses primarily on functional assessments $[4,5]$, on investigating the impact of check dams on the ecosystem [6], or on $\mathrm{CO}_{2}$ emissions [7,8], but no previous studies have examined the regional economic impact of check dams.

The present study quantitatively evaluates the regional economic impact of constructing timber check dams in Japan. In addition, through a comparison with general concrete check dams, we examine the superiority of the regional economic impact of timber check dams.

\section{Methods}

\subsection{Target Region and Target Check Dams}

Akita Prefecture in Japan was selected as the target region. It is located in the north of the main island of Japan and covers an area of about $12,000 \mathrm{~km}^{2}$. Its forest area is about $840,000 \mathrm{ha}$, which accounts for $72 \%$ of the prefecture's area. Its growing stock of forest is about 190 million $\mathrm{m}^{3}$, making it the 7th largest prefecture in Japan in terms of growing forest stock [9]. In addition, it is a region that has positively implemented regional timber use policies, such as the "Akita Prefecture Timber Use Forward Ordinance" [10] and the "Akita Prefecture Timber Use Principle" [11]. As mentioned above, Akita Prefecture was selected because it has abundant forest resources and is an advanced region that promotes regional timber use.

The target check dam is a timber check dam (Figure 1a) ordered by Akita Prefecture in FY2013 and constructed by a company in Kitaakita city, Akita Prefecture. For comparison, we selected a concrete check dam (Figure 1b) ordered by Akita Prefecture in FY2018 and constructed by a company in Yurihonjo city, Akita Prefecture. The target timber check dam was developed in Akita Prefecture. In addition, since it makes use of large-diameter timbers, which are not suitable for general construction, it is expected that check dam construction will be a major source of timber demand. The front and sectional views of the timber check dam are shown in Figure 2. Its body is made of lumber (square timbers) only. The timber check dam includes both the dam body and front apron. Pieces of lumber are piled up so that their fiber direction is orthogonal; they are connected with joint metal fittings (lag screws). For comparison, we selected a concrete check dam, which is the most common type of check dam. The scale of each check dam is shown in Table 1.

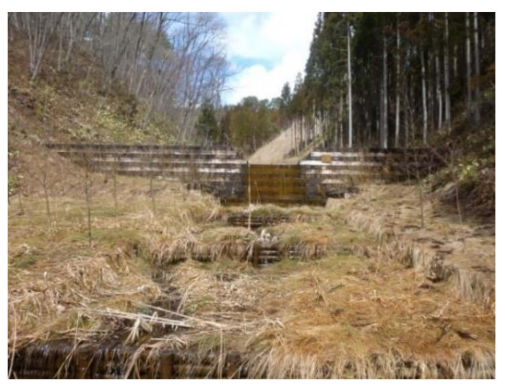

(a)

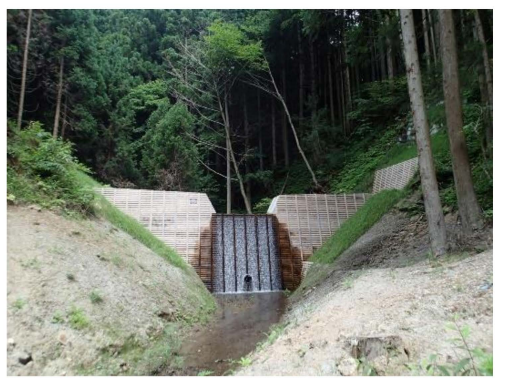

(b)

Figure 1. (a) A timber check dam; (b) a concrete check dam. 
Front view

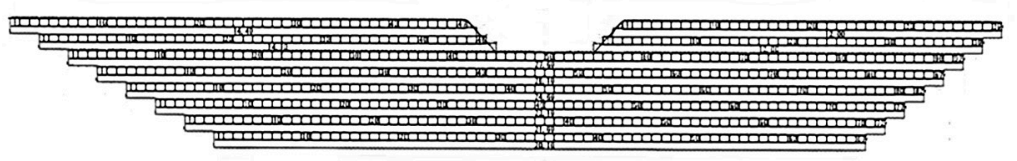

Sectional view

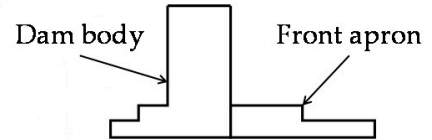

Figure 2. The front and sectional views of a timber check dam.

Table 1. Scale of the targeted check dams.

\begin{tabular}{rlrrrrr}
\hline Area & Type & $\boldsymbol{L}(\mathbf{m})$ & $\boldsymbol{H}(\mathbf{m})$ & $\boldsymbol{W}\left(\mathbf{m}^{\mathbf{3}}\right)$ & $\boldsymbol{C}\left(\mathbf{m}^{\mathbf{3}}\right)$ & $\boldsymbol{S}\left(\mathbf{m}^{\mathbf{3}}\right)$ \\
\hline Akita a & Timber & 30.6 & 3.0 & 241.8 & 0 & 602 \\
Akita b & Concrete & 20.0 & 6.0 & 10.5 & 237.5 & 320 \\
\hline
\end{tabular}

Akita a denotes Kitaakita city, Akita Prefecture; Akita b denotes Yurihonjo city, Akita Prefecture. $L$ is length; $H$ is height; $W$ is lumber consumption; $C$ is concrete consumption; and $S$ is the amount of sediment runoff prevention.

\subsection{Evaluated Range and Process}

The economic impact was evaluated based on the production value induced, the gross value added induced, the employee income induced, and the size of induced employment. The evaluated ranges included the direct, indirect, secondary, and total effects. "Production value induced" is the amount of production generated in each industry to cover the final demand in one industry. "Gross value added induced" falls within "production value induced"; it is the newly generated value induced by the production activity. "Employee income induced" falls within "gross value added induced"; it is the amount of cash or physical income paid to employees. "Size of induced employment" is the number of employees induced in each industry when the final demand is generated in one industry. "Direct effect" is the increase in production generated by the final demand. "Indirect effect" is the amount of production induced by the direct effect. "Secondary effect" is the production amount that is induced by new consumption related to employee income generated from the direct and indirect effects. "Total effect" is a summation of the direct, indirect, and secondary effects.

An input-output table was used to evaluate the economic impact. The procedure was as follows. First, the timber check dam and concrete check dam construction sectors were created in the existing input-output table. Construction revenue and expenditure data were collected from the check dam construction companies. The data were appropriated in the matrix of the newly created sectors, and an extended input-output table (basic transaction table) was developed. Based on this table, an input coefficient table and inverse matrix coefficient table were created. The construction cost of the check dams was considered in the new sectors as the final demand increase amount, and the direct, indirect, and secondary effects were calculated using the above coefficients.

\subsection{The New Sectors}

To evaluate the economic impact, we used the "2011 Akita Prefecture Input-Output Table (108 sectors)" [12], which is the most recent input-output table for Akita Prefecture. Timber check dam construction belongs to the public construction sector in the existing input-output table. However, the public construction sector in the existing input-output table includes structures other than check dams, and the contribution of non-timber structures is particularly large. Therefore, even if timber is used for the target structure, it is not an industrial structure that induces production in timber-related industries. As such, it is difficult to evaluate quantitatively the economic impact of timber check dams that use timber as the main material. In this study, the timber and concrete check dam construction sectors were newly created to quantify the economic impact of timber and concrete check dam construction, respectively. 


\subsection{Construction Revenue and Expenditure Data}

For the creation of the new sectors, detailed construction revenue and expenditure data, such as costs of construction, material, and labor were collected from contractors. Based on the "2011 Input-Output Tables for Japan" [13], published by the Ministry of Internal Affairs and Communications, the construction revenue and expenditure data were classified into the corresponding industrial sectors. Tables 2 and 3 show the materials and expenses, and the corresponding industrial sectors involved in the construction of the timber and concrete check dams, respectively.

Table 2. Timber check dam: Assignment of materials and expenses to sectors.

\begin{tabular}{ccc}
\hline \multirow{2}{*}{ Materials and Expenses } & \multicolumn{2}{c}{ Sector } \\
\cline { 2 - 3 } & Intermediate Sectors & Gross Value Added \\
\hline Lumber & Lumber and wood products & \\
Lag screw & Metal products for construction and architecture & \\
Reinforcing steel & Metal products for construction and architecture & \\
Crushed stone & Non-metallic ores & \\
Cercidiphyllum, & Forestry & \\
Alnus & Crop cultivation & \\
Lawn & Goods rental and leasing services & Wages and salaries \\
Rent (machinery, etc.) & Petroleum refinery products & Indirect tax \\
Utility (fuel) & General-purpose machinery & \\
Facility cost & & Wages and salaries \\
Labor cost & Communication & \\
Tax and public dues & Finance and insurance & \\
Communication cost & Finance and insurance & \\
Construction insurance & Office supplies & \\
Bank guarantee charge & Retirement fund &
\end{tabular}

Table 3. Concrete check dam: Assignment of materials and expenses to sectors.

\begin{tabular}{ccc}
\hline Materials and Expenses & \multicolumn{2}{c}{ Sector } \\
\cline { 2 - 3 } & Intermediate Sectors & Gross Value Added \\
\hline Formwork & Lumber and wood products & \\
Concrete & Cement and cement products & Steel products \\
Laid iron plate & Steel products \\
Deformed steel bars & Petroleum refinery products \\
Fuel cost & Coal products \\
Briquettes & Waste management service & \\
Concrete shell disposal cost & Finance and insurance & \\
Insurance fee & Finance and insurance & \\
Interest & Goods rental and leasing services & \\
Rent (vehicle, machinery, etc.) & Crop cultivation & \\
Lawn & Crop cultivation & \\
Vegetation sandbags & Storage facility service & \\
Material storage fee & Plastic products & Commerce \\
Plastic sheet & Wages and salaries \\
Miscellaneous expenses & & Wages and salaries \\
Labor cost & & Welfare expenses \\
Statutory welfare costs & & Indirect tax \\
Welfare expenses & & \\
Tax and public dues & & \\
\hline & & \\
\end{tabular}




\subsection{Creation of Basic Transaction Table}

Since the revenue and expenditure data collected reflect the purchasers' prices, which include trade margins and domestic freight, we removed both using the Ministry of Land, Infrastructure, and Transport's "summary of trade margin and domestic freights against producers' prices" [14] to calculate producers' prices. The calculated producers' prices were allocated to each column sector in the newly created timber check dam construction sector. The trade margin and domestic freight that were removed were allocated to the commerce and transport sectors (a total of six sectors, such as road transport) of the column sector of the timber check dam construction sector. However, the production activities of the target timber check dam are included in the public construction sector in the existing input-output table. Therefore, the input (expenditure) and output (revenue) of the newly created timber check dam construction sector were deducted from the existing public construction sector to create the expanded input-output table (basic transaction table). The same procedure was applied to create the extended input-output table for concrete check dam construction.

\subsection{Creation of Input Coefficient Table}

"Input coefficients" represent the scale of raw materials and fuel used; they can be obtained by dividing the input of raw materials and fuel used to generate one unit of production in each sector [15]. The input coefficient was calculated using Equation (1), as follows:

$$
a_{i j}=x_{i j} / X_{j}
$$

where $i$ is the row sector number; $j$ is the column sector number; $a_{i j}$ is the input (input coefficient) of $j$ sector from $i$ sector to produce one unit of product; $x_{i j}$ is the input of $j$ sector from $i$ sector; and $X_{j}$ is the prefecture's production of $j$ sector. The input coefficients table (matrix $A$ ) was created based on the extended input-output table.

\subsection{Creation of Inverse Matrix Coefficient Table}

The "inverse matrix coefficient table" indicates how much production will ultimately be induced in which industry for a demand increase of one unit in a certain industry [15]. In this study, we used the competitive import type inverse matrix coefficient table (matrix B), which reflects the fact that a part of the economic impact flows out of the prefecture. The inverse matrix coefficient table was calculated using Equation (2), as follows:

$$
B=(I-(I-M) \times A)^{-1}
$$

where $I$ is the unit matrix; $M$ is a diagonal matrix with import coefficient as the diagonal element and zero as the non-diagonal element; and $A$ is the input coefficient matrix.

\subsection{Setting the Prefecture's Self-Sufficiency Ratios}

The timber used for the targeted timber check dam was all harvested, purchased, and processed in Akita Prefecture. Therefore, to set the prefecture's self-sufficiency ratios for the lumber and wood products and forestry sectors at $100 \%$, the import coefficients for these sectors were set to 0 . The current self-sufficiency ratios in Akita Prefecture are $40 \%$ in the lumber and wood products sector and $88 \%$ in the forestry sector. Therefore, the current import coefficients are 0.60 and 0.12 , respectively. 


\subsection{Evaluation of the Economic Impact}

The economic impact evaluation procedure is shown in Figure 3. The construction cost of the check dams was considered as the final demand increase, and the economic impact was then evaluated.

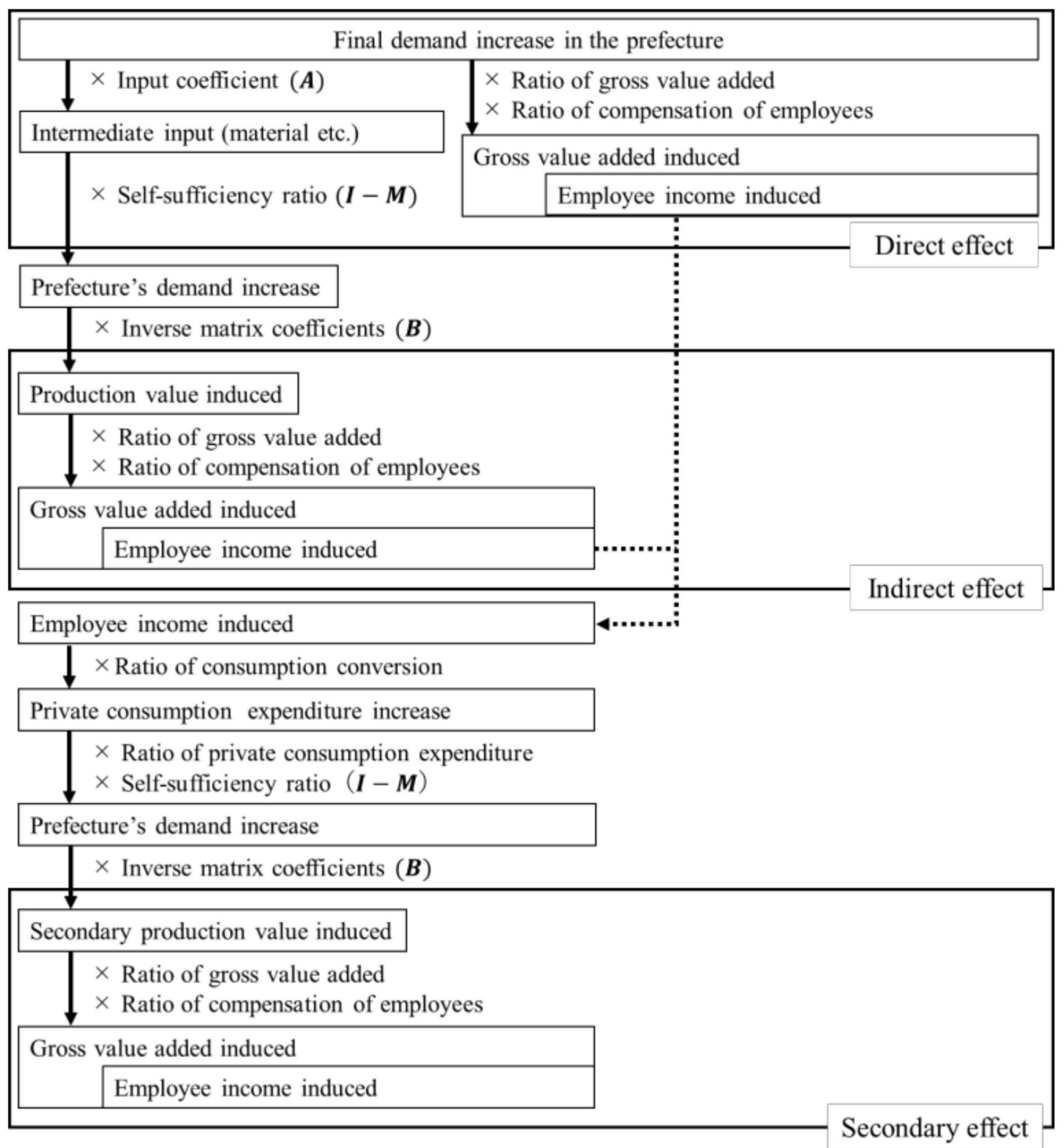

Figure 3. The economic impact evaluation procedure.

The ratio of gross value added was defined as the gross value added of each sector divided by the prefecture's production for that sector. The ratio of employee income was defined as the income of employees in each sector divided by the prefecture's production for that sector. The ratio of consumption conversion was defined as the consumption expenditure divided by the real income, using the "Family income and expenditure survey, household income and expenditure part, total household details result table" $[16,17]$. The ratio of private consumption expenditure was defined as the consumption expenditure of each sector divided by the total consumption expenditure. 


\subsection{Evaluation of the Size of Induced Employment}

The size of induced employment was evaluated using the induced employment ratio. For each sector, the induced employment ratio was derived by dividing the number of employees by the production values. However, for the induced employment ratio of the newly created timber check dam construction and concrete check dam construction sectors, the induced employment ratio of the existing public construction sector was used because reliable data could not be collected. The size of induced employment from the direct effect was evaluated by multiplying the final demand increase in the prefecture (timber check dam or concrete check dam construction sector) by the induced employment ratio (public construction sector). The size of induced employment from the indirect effect was evaluated by multiplying the production value induced by each sector from the indirect effect of the induced employment ratio of each sector. The size of induced employment from the secondary effect was evaluated by multiplying the production value induced by each sector from the secondary effect of the induced employment ratio of each sector. The size of induced employment from the total effect is the accumulated size of induced employment from the direct, indirect, and secondary effects.

\subsection{Unifying the Amount of Sediment Runoff Prevention}

The amount of sediment runoff prevention, one of the functions of a check dam, differs between the timber and concrete check dams. As shown in Table 1, the amounts of sediment runoff prevention from the timber and concrete check dams are $602 \mathrm{~m}^{3}$ and $320 \mathrm{~m}^{3}$, respectively. Therefore, to compare the magnitude of the regional economic impact on the functions of the check dam, the amount of sediment runoff prevention created by the concrete check dam was unified with that of the timber check dam. The respective amounts were calculated using Equation (3) [18] to (6), as follows:

$$
\begin{gathered}
V=\frac{b h l}{2} \\
l=\frac{h}{n-m} \\
n-m=\frac{\mathrm{n}}{2} \\
V=\frac{b h^{2}}{n}
\end{gathered}
$$

where $V\left(\mathrm{~m}^{3}\right)$ is the amount of sediment runoff prevention; $b(\mathrm{~m})$ is the average width of the storage area; $h(\mathrm{~m})$ is the height above the stream bed; $l(\mathrm{~m})$ is the horizontal distance of the sediment area; $m(\%)$ is the designed slope; and $n(\%)$ is the slope of the stream bed.

In this study, to unify the amounts of sediment runoff prevention for the concrete and timber check dams, the height of the concrete check dam was increased. This correspondingly raised the amount of sediment runoff prevention. The increased amount of concrete and formwork (plywood) were calculated to be $30.5 \mathrm{~m}^{3}$ and $1.3 \mathrm{~m}^{3}$, respectively. The price per $\mathrm{m}^{3}$ of concrete and formwork was calculated from the revenue and expenditure data, and the increase in the cost of materials was calculated by multiplying the increased quantity used by their respective unit prices. As for the labor cost, the increase in the number of days for concrete placement was calculated based on the amount of concrete used, using the "Tohoku Regional Forest Office design estimation data" [19]. The calculated number of days for concrete placement increased by 0.61 days, which was multiplied by the construction unit price [19] and labor unit cost [20]. This information was used to calculate the increase in the labor cost. In this way, the regional economic impact of the construction of a concrete check dam was evaluated with the same amount of sediment runoff prevention as that for the timber check dam. 


\section{Results}

\subsection{The Regional Economic Impact of a Timber Check Dam and a Concrete Check Dam}

Tables 4 and 5 present an evaluation of the economic impact of constructing a timber check dam and a concrete check dam, respectively. The 30,000,000 yen construction cost of a timber check dam was considered to be the final demand increase of the timber check dam construction sector. As a result, the production value induced was 58,323,000 yen; the gross value added was 25,945,000 yen; and the employee income was 15,264,000 yen. The sizes of induced employment from the direct, indirect, secondary, and total effects were 3.58, 1.72, 0.70, and 6.00 people, respectively. The 15,556,000-yen construction cost of the concrete check dam was considered to be the final demand increase of the concrete check dam construction sector. As a result, the production value induced was 27,001,000 yen; the gross value added was 12,993,000 yen; and the employee income induced was 8,713,000 yen. The sizes of induced employment from the direct, indirect, secondary, and total effects were $1.86,0.57$, 0.38 , and 2.81 people, respectively.

Table 4. The economic impact of constructing a timber check dam (unit is thousand yen).

\begin{tabular}{ccccc}
\hline & Direct Effect & Indirect Effect & Secondary Effect & Total Effect \\
\hline Production value induced & 30,000 & 20,348 & 7975 & 58,323 \\
Gross value added induced & 10,129 & 10,727 & 5088 & 25,945 \\
Employee income induced & 8715 & 4685 & 1864 & 15,264 \\
\hline
\end{tabular}

Table 5. The economic impact of constructing a concrete check dam (unit is thousand yen).

\begin{tabular}{ccccc}
\hline & Direct Effect & Indirect Effect & Secondary Effect & Total Effect \\
\hline Production value induced & 15,556 & 6897 & 4548 & 27,001 \\
Gross value added induced & 6044 & 4046 & 2903 & 12,993 \\
Employee income induced & 5951 & 1700 & 1063 & 8713 \\
\hline
\end{tabular}

\subsection{Comparison after Unifying Construction Costs}

It is difficult to compare the economic impact of the construction of timber and concrete check dams in monetary terms because their construction costs are different. To compare the magnitude of the regional economic impact, we assumed that the construction cost (final demand increase) of the concrete check dam was 30,000,000 yen, the same as the cost of the timber check dam. Table 6 shows the evaluation of the economic impact of constructing a concrete check dam with unified construction costs.

Table 6. The economic impact of constructing a concrete check dam (after unifying construction costs; unit is thousand yen).

\begin{tabular}{ccccc}
\hline & Direct Effect & Indirect Effect & Secondary Effect & Total Effect \\
\hline Production value induced & 30,000 & 13,301 & 8421 & 51,722 \\
Gross value added induced & 11,656 & 7803 & 5374 & 24,833 \\
Employee income induced & 11,476 & 3278 & 1968 & 16,722 \\
\hline
\end{tabular}

After unifying the costs, the production value induced was 51,722,000 yen; the gross value added was 24,833,000 yen; and the employee compensation induced was 16,722,000 yen. The sizes of induced employment from the direct, indirect, secondary, and total effects were 3.58, 1.09, 0.74, and 5.41 people, respectively. In addition, the economic impact ratios (ratio of total effect to direct effect) were 1.94 and 1.72 for the timber and concrete check dams, respectively. 
Tables 7 and 8 show the top five sectors for the indirect and secondary effects of constructing a timber check dam and concrete check dam, respectively. The top five sectors for the indirect effects of timber check dam construction were, in order, lumber and wood products, commerce, goods rental and services, forestry, and road transport (except for self-transport). The top five sectors for the indirect effects of concrete check dam construction, in order, were goods rental and leasing services, commerce, cement and cement products, finance and insurance, and road transport (except for self-transport). The top five sectors for the secondary effects were, in order, house rent (imputed house rent), commerce, finance and insurance, communication, and eating and drinking services for both timber and concrete check dam construction. The secondary effects showed the economic impact related to general consumption activities on the industrial sector.

Table 7. The top five sectors for the indirect and secondary effects of constructing a timber check dam (unit is thousand yen).

\begin{tabular}{cccc}
\hline \multicolumn{2}{c}{ Indirect Effects } & \multicolumn{2}{c}{ Secondary Effects } \\
\hline Sector & & Sector \\
\hline Lumber and wood products & 8487 & House rent (imputed house rent) & 1465 \\
Commerce & 3175 & Commerce & 1065 \\
Goods rental and leasing services & 1986 & Finance and insurance & 605 \\
Forestry & 1820 & Communication & 426 \\
Road transport (except self-transport) & 1118 & Eating and drinking services & 338 \\
\hline
\end{tabular}

Table 8. The top five sectors for the indirect and secondary effects of constructing a concrete check dam (unit is thousand yen).

\begin{tabular}{cccc}
\hline Indirect Effects & \multicolumn{2}{c}{ Secondary Effects } \\
\hline Sector & & Sector & 1548 \\
Goods rental and leasing services & 3140 & House rent (imputed house rent) & 1126 \\
Commerce & 2810 & Commerce & 639 \\
Cement and cement products & 2180 & Finance and insurance & 450 \\
Finance and insurance & 1317 & Communication & 357 \\
Road transport (except self-transport) & 646 & Eating and drinking services & \\
\hline
\end{tabular}

\subsection{Comparison by Unifying the Amount of Sediment Runoff Prevention}

Table 9 shows the economic impact of constructing a concrete check dam when the amount of sediment runoff prevention is unified with that of the timber check dam. The production value induced was 28,186,000 yen; the sizes of induced employment from the direct, indirect, secondary, and total effects were $1.95,0.61,0.40$, and 2.95 people, respectively; and the economic impact ratio was 1.73.

Table 9. The economic impact of constructing a concrete check dam (after unifying the amount of sediment runoff prevention; unit is thousand yen).

\begin{tabular}{ccccc}
\hline & Direct Effects & Indirect Effects & Secondary Effects & Total Effects \\
\hline Production value induced & 16,316 & 7330 & 4540 & 28,186 \\
Gross value added induced & 6295 & 4289 & 2897 & 13,482 \\
Employee income induced & 6131 & 1822 & 1061 & 9014 \\
\hline
\end{tabular}




\section{Discussion}

\subsection{Comparison between the Construction of a Timber Check Dam and a Concrete Check Dam}

The construction fiscal years are different for the concrete check dam (FY2018) and the timber check dam (FY2013). Therefore, we considered the influence of the inflation ratio in FY 2013 and FY 2018 on the regional economic impact of the concrete check dam construction. Using construction cost deflators from FY 2013 to FY 2018 [21], the construction cost of the concrete check dam in FY2018 was converted to that in FY2013 when the timber check dam was constructed. The converted construction cost of the concrete check dam is $14,162,000$ yen. As a result, the production value induced is $24,418,000$ yen, and the economic impact ratio is 1.72. A comparison of the economic impact ratios between the converted cost and the current cost (Table 5) shows only minor differences $(0.007 \%)$. Therefore, the difference attributable to inflation is considered to have a small impact on the results. As such, it is plausible to compare the regional economic impact between the timber and concrete check dams despite the difference in construction years.

When unifying construction costs (see Tables 4 and 6), the total effect of the concrete check dam construction is about $13 \%$ smaller than that of the timber check dam. In brief, compared with the concrete check dam construction, the timber check dam construction has a larger regional economic impact. By contrast, the secondary effect of the concrete check dam construction is about $6 \%$ larger than that of the timber check dam construction because the ratio of labor cost to construction cost for the timber (concrete) check dam is $29 \%$ (39\%). Concrete check dams are considered to increase labor costs due to increases in the construction process for items such as concrete form construction and concrete curing. Thus, the consumption activity triggered by production, that is, the secondary effects, of the concrete check dam are deemed to be larger than those of the timber check dam. The size of induced employment from the total effect is larger for the timber check dam construction. The size of induced employment from the indirect (secondary) effect is 0.63 people more ( 0.04 people less) for the timber check dam construction as compared with the concrete check dam construction. It is considered that this is because the employee income induced by the concrete check dam construction is larger than that induced by the timber check dam construction.

With respect to the top five sectors for the indirect effects (Tables 7 and 8), as the indirect effects became larger for the lumber and wood products and forestry sectors in the timber check dam construction, and larger for the cement and cement products for the concrete check dam construction, the economic impact on the industries that produce the main materials of these check dams was also enlarged. In addition, the indirect effects also became larger for the commercial sector, including the retail and wholesale sectors, and the road transport sector involved in the transportation of materials.

As the total effect was larger for the timber check dam construction, the indirect effects for the top five sectors and the size of induced employment were also larger, thus making it more likely for the timber (versus the concrete) check dam to revitalize the regional economy. Further, the targeted check dams were public works projects, not private businesses, and while private businesses tend to keep construction costs low, public works may create jobs and revitalize the regional economy by circulating goods to various industries in the region, even if the order costs are high.

In the cases where the amounts of sediment runoff prevention were unified (Tables 4 and 9), the construction cost of the concrete check dam was lower than that of the timber check dam. However, in terms of the economic impact ratios, the regional economic impact was about $12 \%$ larger for the timber versus the concrete check dam construction. Thus, the timber check dam construction had a larger regional economic impact than the concrete check dam, even when the functional units were unified. 


\subsection{Lumber Prices and Regional Self-Sufficiency Ratios for Timber Check Dam Construction}

As mentioned above, the construction of the timber check dam had a large economic impact on timber-related industries such as the lumber and wood products sector and the forestry sector. Therefore, we consider the influence of the prefecture's self-sufficiency ratios in these sectors on the regional economic impact of the timber check dam construction. Figure 4 shows the impact of the change in the prefecture's self-sufficiency ratios in the said sectors on the total effect.

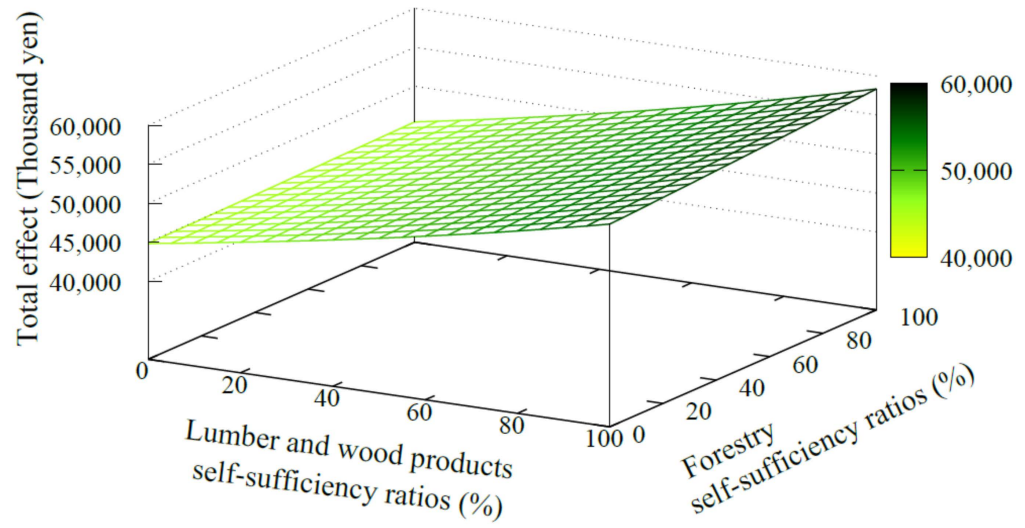

Figure 4. Impact of changes in the prefecture's self-sufficiency ratios for the lumber and wood products and forestry sectors on the total effect.

The total effect is proportional to the increase in the lumber and wood products sector's self-sufficiency ratio (horizontal axis) and the forestry sector's self-sufficiency ratio (depth axis). However, the impact on the increase in the total effect was more modest in the forestry sector's self-sufficiency ratio than in the lumber and wood products sector's self-sufficiency ratio. Therefore, it is shown that using processed timber for flood control has a larger effect on the regional economic impact than using timber harvested in the region. Moreover, the total effect increased gently as the forestry sector's self-sufficiency ratio increased; thus, the use of harvested timber in the region clearly has a positive economic impact.

Figure 5 shows the impact of a change in the prefecture's self-sufficiency ratio for the lumber and wood products sector and the lumber price on the total effect when the regional self-sufficiency ratio of the forestry sector is $100 \%$. The total effect of a concrete check dam construction, unified with the construction cost of the timber check dam, is also shown for comparison.

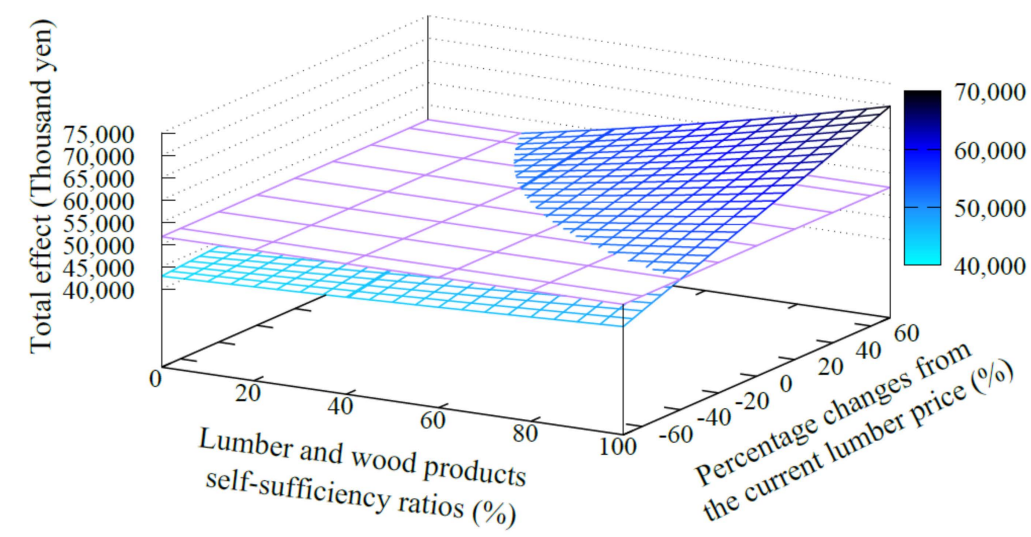

Figure 5. Impact of changes in the prefecture's self-sufficiency ratios for the lumber and wood products sectors and the lumber price on the total effect (blue), and the total effect of the concrete check dam construction (violet). 
When the lumber price remains unchanged and the regional self-sufficiency ratio for the lumber and wood products sector is $56 \%$ or more, or when the lumber price is $125 \%$ or more of its current price and the regional self-sufficiency ratio for lumber and wood products sector remains stable $(40 \%)$, the total effect of a timber check dam construction is larger than that of a concrete check dam construction. However, when the self-sufficiency ratio of the lumber and wood products sector is about $20 \%$ or less, the total effect of a timber check dam construction is lower than that of a concrete check dam construction, even if the lumber price is $170 \%$ of its current price. Therefore, with a constant lumber price, processing less lumber in the region has a negative effect on the regional economy. When the lumber price is about $60 \%$ of the current price, the total effect of a timber check dam is less than that of the concrete check dam, even if the regional self-sufficiency ratio of the lumber and wood products sector is $100 \%$. For this reason, in timber check dam construction, procuring inexpensive timber and reducing construction costs may be a trade-off for the revitalization of the regional economy.

In regions where the regional self-sufficiency ratio of the lumber and wood products sector is very low, it is likely that the regional economic impact of the concrete check dam is larger than that of the timber check dam. When the regional self-sufficiency ratio for the lumber and wood products sector is $10 \%$, for the total effect of the timber check dam construction to be greater than that of the concrete check dam construction, the lumber price must be more than $211 \%$ of its current price. The significant rise in lumber prices required to increase the regional economic impact is deemed to be excessively high. As such, construction of the concrete check dam is considered to have greater regional economic impact than the timber check dam. In addition, since importing lumber reduces the regional self-sufficiency ratio of the lumber and wood products sector, this makes the regional economic impact smaller. When constructing a timber check dam, increasing the self-sufficiency ratio of lumber and wood products will have a positive effect on the local economy.

\section{Conclusions}

Targeting Akita Prefecture, Japan, we developed an extended input-output table with two newly created sectors: the timber check dam construction and the concrete check dam construction sectors. This table was used to evaluate the economic impact of a timber check dam construction compared with a concrete check dam construction. The following are the main takeaways from the study.

1. The regional economic impact of a timber check dam construction is $58,323,000$ yen (the economic impact ratio is 1.94), and the construction cost (direct effect) is 30,000,000 yen. Above all, the results show that the impacts on timber-related industries, such as the lumber and wood products sector and the forestry sector, are significant.

2. The construction cost of the concrete check dam is $15,556,000$ yen, and the regional economic impact is $27,001,000$ yen (the economic impact ratio is 1.74). After unifying the construction costs for the timber and concrete check dams, the economic impact ratio of the concrete check dam construction becomes 1.72. After unifying the amount of sediment runoff prevention, the economic impact ratio becomes 1.73 .

3. A comparison between the timber and concrete check dam construction, in terms of construction cost and amount of sediment runoff prevention, shows that the timber check dam construction has a larger economic impact on the region and a more positive impact on the regional economy.

4. When the regional self-sufficiency ratio of the lumber and wood products sector is less than about $20 \%$, the economic impact of timber check dam construction is smaller than that of concrete check dam construction; thus, it is important to harvest, process, and use timber regionally to contribute to the regional economy. 
5. When the lumber price is about $60 \%$ of the current price, even if the self-sufficiency ratio of the lumber and wood products sector is $100 \%$, the economic impact is smaller than that of concrete check dam construction; thus, there is no chance that reducing construction costs by procuring regionally processed timber at low prices would contribute to the revitalization of the regional economy.

The concrete check dam targeted in this study is a common type of check dam, but the timber check dam is a relatively new type that is made entirely of timber. In Japan, timber check dams are generally constructed out of timber in a lattice-shaped structure and filled with crushed stones to secure the weight of the dam. As such, it is also necessary to consider the possibility of different results when evaluating the economic impact of other types of timber check dams.

This study demonstrates the importance of considering the regional economic impact when selecting which type of check dam to construct, and it can provide options for proactive timber use. This study also shows that using timber for check dam construction may have a positive impact on the regional economy, which is expected to contribute to the economic revitalization of regions centering on timber-related industries.

Author Contributions: Conceptualization, T.H., R.N., and C.K.; methodology, T.H., R.N., and C.K.; data curation, T.H., R.N., and C.K.; writing-original draft preparation, T.H.; writing-review and editing, T.H., R.N., and C.K.; funding acquisition, C.K. All authors have read and agreed to the published version of the manuscript.

Funding: This work was supported by the Sumitomo Foundation Fiscal 2019 Grant for Environmental Research Projects (grant number 193259) and JSPS KAKENHI (grant number JP20H04384).

Acknowledgments: We are deeply grateful to the construction contractors and Akita Prefecture for providing invaluable data and assistance for this study.

Conflicts of Interest: The authors declare no conflict of interest.

\section{References}

1. Forestry Agency. Annual Report on Forest and Forestry in Japan (Fiscal Year 2019); Forestry Agency: Tokyo, Japan, 2020.

2. Kyoto Prefecture Timber Check Dams Commentary. Available online: http://www.pref.kyoto.jp/forest/ mokudamu/kaisetsu.html (accessed on 8 July 2020).

3. Noda, R.; Sasaki, T.; Chida, T.; Inoue, T.; Harata, T.; Miura, Y. Development of original wooden check dam in Akita Prefecture. J. Jpn. Soc. Eros. Control Eng. 2012, 65, 39-46.

4. Yuan, D.; Liu, J.; You, Y.; Liu, D.; Sun, H.; Zhang, L.; Zhou, W. The siltation of debris flow behind check dam in the midstream of Bailong River. J. Mt. Sci. 2018, 15, 100-113. [CrossRef]

5. Liu, J.; Nakatani, K.; Mizuyama, T. Hazard mitigation planning for debris flow based on numerical simulation using Kanako simulator. J. Mt. Sci. 2012, 9, 529-537. [CrossRef]

6. Bombino, G.; Fayos, B.C.; Gurnell, M.A.; Tamburino, V.; Zema, A.D.; Zimbone, M.S. Check dam influence on vegetation species diversity in mountain torrents of the Mediterranean environment. Ecohydrology 2014, 7, 678-691. [CrossRef]

7. Noda, R.; Kayo, C.; Sasaki, T.; Takaoku, S. Evaluation of $\mathrm{CO}_{2}$ emissions reductions by timber check dams and their economic effectiveness. J. Wood Sci. 2014, 60, 461-472. [CrossRef]

8. Kayo, C.; Noda, R.; Sasaki, T.; Takaoku, S. Carbon balance in the life cycle of wood: Targeting a timber check dam. J. Wood Sci. 2015, 61, 70-80. [CrossRef]

9. Akita Prefecture Forest and Forestry Overview (FY 2020 Version). Available online: https: //www.pref.akita.lg.jp/uploads/public/archive_0000001769_00/\%E7\%A7\%8B\%E7\%94\%B0\%E7\%9C\%8C\% E6\%A3\%AE\%E6\%9E\%97\%E3\%83\%BB\%E6\%9E\%97\%E6\%A5\%AD\%E3\%81\%AE\%E6\%A6\%82\%E8\%A6\% 81\%EF\%BC\%88\%E4\%BB\%A4\%E5\%92\%8C2\%E5\%B9\%B4\%E5\%BA\%A6\%E7\%89\%88\%EF\%BC\%89.pdf (accessed on 8 July 2020).

10. Akita Prefecture Timber Use Forward Ordinance. Available online: https://www.pref.akita.lg.jp/uploads/ public/archive_0000010716_00/0001.pdf (accessed on 8 July 2020). 
11. Akita Prefecture Timber Use Principle. Available online: https://www.pref.akita.lg.jp/uploads/public/ archive_0000000468_00/\%EF\%BC $\% 91 \% \mathrm{E} 3 \% 80 \% 80 \% \mathrm{E} 7 \% 9 \mathrm{C} \% 8 \mathrm{C} \% \mathrm{E7} \% 94 \% \mathrm{A3} \% \mathrm{E} 6 \% 9 \mathrm{D} \% 90 \% \mathrm{E} 5 \% 88 \% \mathrm{~A} 9 \%$ E7\%94\%A8\%E6\%8E\%A8\%E9\%80\%B2\%E6\%96\%B9\%E9\%87\%9D\%EF\%BC\%88H30.6.4\%E4\%B8\%80\%E9\% 83\%A8\%E6\%94\%B9\%E6\%AD\%A3\%EF\%BC\%89.pdf (accessed on 8 July 2020).

12. 2011 Akita Prefecture Input-Output Table. Available online: http://www.pref.akita.lg.jp/pages/archive/31259/ (accessed on 8 July 2020).

13. Ministry of Internal Affairs and Communications. 2011 Input-Output Tables for Japan, Chapter VII: Concept, Definition and Scope by Sector. Available online: https://www.soumu.go.jp/main_content/000443188.pdf (accessed on 8 July 2020).

14. Ministry of Land, Infrastructure and Transport. 2011 Input-Output Table Centering on the Transportation Sector, Summary of Trade Margin and Domestic Freights against Producers' Prices. Available online: http://www.mlit.go.jp/common/001277156.pdf (accessed on 8 July 2020).

15. Ministry of Internal Affairs and Communications. 2011 Input-Output Tables for Japan, Chapter IV: Coefficients for Input-Output Analysis and Computation Methods. Available online: https://www.soumu.go.jp/main content/000443188.pdf (accessed on 8 July 2020).

16. Ministry of Internal Affairs and Communications. 2013 Family Income and Expenditure Survey, Household Income and Expenditure Part, Total Household Details Result Table. Available online: https://www.e-stat.go.jp/stat-search/files?page=1\&layout=datalist\&toukei=00200561\&tstat=000000330001\& cycle $=7 \&$ year $=20130 \&$ month $=0 \&$ tclass $1=000000330001 \&$ tclass $2=000000330019 \&$ tclass $3=000000330020 \&$ stat_infid=000023621400\&result_back $=1$ (accessed on 8 July 2020).

17. Ministry of Internal Affairs and Communications. 2018 Family Income and Expenditure Survey, Household Income and Expenditure Part, Total Household Details Result Table. Available online: https://www.e-stat.go.jp/stat-search/files?page=1\&layout=datalist\&toukei=00200561\&tstat=000000330001\& cycle $=7 \&$ year $=20180 \&$ month $=0 \&$ tclass $1=000000330001 \&$ tclass $2=000000330019 \&$ tclass $3=000000330020 \&$ stat_infid=000031795506\&result_back $=1$ (accessed on 8 July 2020).

18. Suyama, M. On the evaluation of effectiveness for forest conservation works-A case study of forest conservation projects for non-national forests under direct control of national government at Sojyagawa-district. Trans. Kansai Branch Jpn. For. Soc. 1994, 3, 185-188.

19. Tohoku Regional Forest Office: Tohoku Regional Forest Office Design Estimation Data (Mountain Control and Forest Road Construction). Available online: https://www.rinya.maff.go.jp/tohoku/keiri/pdf/1_9_ sekkeisekisannsiryou_tisann_rinndou_2804.pdf (accessed on 8 July 2020).

20. Ministry of Land, Infrastructure and Transport. About Public Works Design Labor Unit Cost to Apply from March 2018. 2018. Available online: https://www.mlit.go.jp/common/001221741.pdf (accessed on 8 July 2020).

21. Ministry of Land, Infrastructure, Transport and Tourism. Construction Cost Deflator FY 2018. Available online: https:/www.e-stat.go.jp/stat-search/file-download?statInfId $=000031859400 \&$ fileKind $=0$ (accessed on 18 September 2020).

(C) 2020 by the authors. Licensee MDPI, Basel, Switzerland. This article is an open access article distributed under the terms and conditions of the Creative Commons Attribution (CC BY) license (http://creativecommons.org/licenses/by/4.0/). 